阪本岩千代 (株) 大阪電氣商会管工部主任 鈴木阳夫程井輸出織物染色工業会

常珯理 事

木地台一木地金筬製作所專務取締役

森川䐂三大日本紡績(株) 研究部機栈課

小野勝也倉紡本社企面課

佐筡忠

泉本元一

堀江新䄓并精練加工(株)

前田昭美

高木繁高木絹織工場

邽部松三郎芦屋棉業(株) 工場 長

宇野浩三與國入絹入代工場

桶上三夫日本シール(株)

高不良本

森川孝士大和紡繢福井工埸

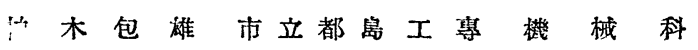

留原鹤夫全沢大学工学部助教授

山田義一日棉実業(怢)名古晊支店

就 貨 部

山田三郎大同毛織(株) 工務部原留

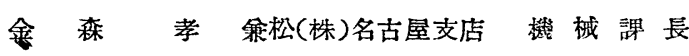

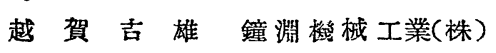

上村正田铁工所

高取才助帝团撚系織物(株) 取締役防長

伊藤友吉郡是製系(株) 技師

学 生 僉 員

土忠東京大学第一工学部 機 械 科

僉 員 異 動

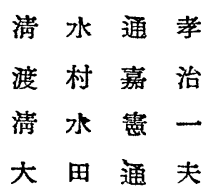

中央毛織（株）津工場に轉勤

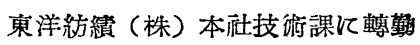

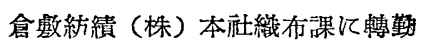

日本治金工業（株）金沢精器工場飞 就職

小口登東京都目黑区大岡山東宗工大弓道場 內に轉居

足立 丈 保京都府形知山市口榎原に轉居

吉 村 昇 東京都世田谷区玉川奧沢 町 2 の 134 吉村鋯一方傅居

吉田毅京都市左京区高野竹屋町金紡中社笔 9 号內に轉居
中田厚北國精器 (炇) 飞就僟

池 野 昭 二 津田駒工場 (怢) 飞就職

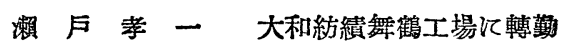

丙田诚敷島紡績戶畑工場飞轉僅

撮野昭三丸山工業小杉工場 ”

宮䐀卓司大東紡織高塚工場 ”

加藤一一男 興國毛織 (蛛) "

鈴木吉治 富土紡大分工場 ”

小林 正治 三菱化成岐鼻工場 ”

逝去

本会関東支部役員今泉吉太郎氏(株式会社今泉メリヤ ス機械製造所社長) は本年 1 月 21 日急逝されました。 諢しんて哀槕の意を表します。

\section{事務所・電 話}

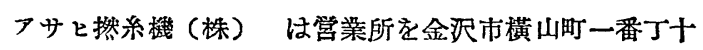
番地の本社工場内移霜 電話7215

西部織物慜造（株）は事務所を泉大津市春日町六八に 移轉

丸山工業 (株) は事弱所を大阪市東区南本町三丁 目八に移轉

日本空素畞料水俣工場 は新日本窒素盵料水俣工場と改 名

渡辺媻 作 所 は (株) 渡辺鉄工所飞改名

日本毛織（株）は電話番号を次ぎの通り変更 摹合(2)(代表)601701营合(2)602 $5 \quad 702 \sim 5$

正 誤 表

頁湖一行正 - 䛜

[17号（25年1月）石川章一報交]

18 著者名出田治夫山口治夫

20 左 IV 項 8 行目 CWCよりむ EWCょりあ

21 右 第 4 表最右欄 表面上のひずみ 裹面上のひず

21 右 最下行

第 4.表最右欄 第 5 表

[17号安永一三報文]

7 左下上り13行目 同室の室容量は 同室の室容量 $13,300 \times 15 \quad$ は $13,300 \times$ $=200,000 \mathrm{c} f \quad 200,000 \mathrm{c} f$ t

7 右下上り 12 行 1 時間 1 回. 1 時間飞 $1^{\circ} \oslash$ 
頁期

IE

哭

8 左 17 行

空篓洗洒器に

電氣珗㵀器老

【17号阪本久五郎・呞川壾報交】

14. 右 10

15 右 4

" " 6

16 右 10

\section{断続 \\ 断結 \\ 第1 日(配線因) 第1（因配線}

因)

a) d) f)

運動 a) a) f)

運働
【18号（昭和25年 2 月）阪本久五郎論說交）

1 左 7

7 71

/1 右 13

3. 左 17

”右 21

5 左 7

/1 右 13
緎維系江対する 機械の研究

連続繊誰系

機械

糸層

得るとと

殆よ゙

カーブカム
繊維系に対す 万研究

連結繊維系

械機

系展

得るごと

絕㸚化

カープカム

\section{前號短評}

正会員 $\mathrm{S} . \mathrm{W}$.生

第18号の焦点はシヤツトル砰究座談會にあつたと思す れる。研究報交中の澤木氏「シャツトルに關する研究」 を中心として、硬度、トングの緩み、糸切れ等について 討論が行われているが示晙に富し好䛃物であつた。硬度 は本均值のせいか、活ぼ一定であるが、もし変動率が大 きいとすれば、材糊の選択に問題を残すことになる。そ うだとすればショア硬度計により現場でも、簡單に選材 しうるのてはなかろうか。また紛れ試驗む、動的な考 察のもとに更に発展させて㳊しい問題てある。厉本氏の 「化学繊維製織用機械に就いて」と「コーンワインダーの 研究」を読んて、ての方面の機械のもつかしさが分る。 すで殆ど完成されたとみてよい天然瀻維用機械とちが い、化学緎維用機械は、瀻維そのもの之之もに発展の途 上飞ある。はやくあ世界的水準を超えんとしつつあるこ とは窨ばしい。㮌後氏の「綿紡打綿のヒーター・フレー ドの設計」は、ミスプリントのせいもあつて紫読しかね る。てのような强度計算は、隅間のアールに上る切欠奻 果の方が大切ではないか。また綿の量が分つていれば、 たとえばシャルビの衝撃試驗機て打綿時のエネルギーを
求めることはできないだろうか。谷下、植田両氏の「織 維の乾燥に就いて」は表題を織物の乾燥とすべきだつ た。たしかにメリヤス穎は、吹找け乾燥の方が讼経消上 よいことが分るが、普诵の織物でも適当な方法を用いれ

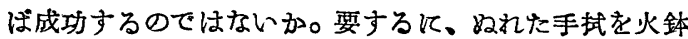
の上で垂直にして乾かすか、水本にして乾かすかの差で あると言える。けだし実驗範团に関するかぎり、精細致 密なよい報告であると思う。岡部氏「スクリブラーカー ドに於けるストリツパーの表面速度」は紡毛機研究会の 試驗報告として敬意を表するすのである。よく整理され たデータを見ると更に慾が出るものであるが、機械の調 整によつて、表面速度增加時の欠点が除去されないすの であるうか。たとえば速度の增加にしたがつてグージ 大きくすれば、强力が少しは改善されないか等々。てん なととが品質管理の問题とも関連するが、青木、川角両 氏の「紡績工場の品質管理」はいよいよ本論に入つた。 多くの例題が挿入されて、頭の惡い評者にもよく分つた が、次昘もての倜子で、て杂以上難しくならざらんてと を望む。最後になつたが、鳥菱會長の渡米は、本学会と して豆ばしいてとて、㴆國後の見聞記が待たれるととも 飞、送別会上での各界名士のテーブルスビーキが、今後 す論說として揭載されるであろうが、大い期待してい るとてろである。

\begin{tabular}{|c|c|}
\hline 昭和25年 3 月10日政行 & $\begin{array}{r}\text { 定價 金60 円 } \\
\text { (卼科 } 3 \text { 円) }\end{array}$ \\
\hline 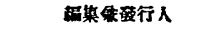 & 野 \\
\hline & 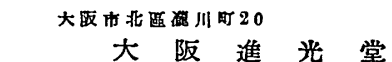 \\
\hline 発 行 所 & 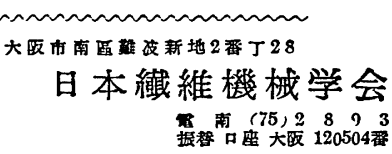 \\
\hline
\end{tabular}

